\title{
DISCURSO EM HOMENAGEM A HELENO TAVEIRA TORRES
}

TRIBUTE SPEECH TO HELENO TAVEIRA TORRES

Regis Fernandes de Oliveira*

Uma foto que chocou o mundo foi a da criança Aylan Kurdi, de três (3) anos morta por afogamento à beira do mar, com sua camisa vermelha, bermuda e tênis azuis. A foto é o retrato da solidão e da vergonha que apavoram o mundo. É importante que consigamos ver através dela a mensagem que transmite.

É o que Giorgio Agamben denomina do contemporâneo no mundo, ou seja, não é ver o que todos veem, mas detectar o buio, ou enxergar no escuro. Diz Agamben que "o contemporâneo é aquele que percebe o escuro do seu tempo como algo que lhe concerne e não cessa de interpelá-lo, algo que, mais do que toda luz, dirige-se direta e singularmente a ele" (“O que é o contemporâneo? E outros ensaios", ed. Argos, p. 64).

Enxergar não é ver e ver não é compreender.

No mundo jurídico, há aqueles que se entretêm em ler a lei; outros, a interpretá-la. Alguns visualizam apenas normas e suas conotações sintáticas e até mesmo semânticas, mas sem saber o que está por detrás do fato. $\mathrm{O}$ direito não é feito para usufruto orgástico de seu leitor. É criado para disciplinar pessoas em seu relacionamento com outras pessoas. Daí muitos fazerem leitura rasteira e vesga do direito. Outros, arriscam o altum sapere periculosum, ou seja, desafiar o infinito, nele não encontrando limites nem horizontes. É saber que o alto saber não é perigoso.

Heleno Torres é da estirpe destes últimos. O homem que hoje toma posse solene no cargo de Professor Titular de Direito Financeiro da Faculdade de Direito de São Paulo é dos que vê, interpreta e busca soluções para o mundo de hoje. É o que participa e não se omite.

Heleno é dos homens que veem no escuro.

Formou-se pela Faculdade de Direito da Universidade Federal de Pernambuco, em 1992, e já em 1995 era Mestre pela mesma Universidade e em 1999 era doutor pela Pontifícia Universidade Católica de São Paulo, logrando obter a LivreDocência na Faculdade de Direito da USP já em 2002. No entremeio fez especialização junto à Università degli Studi di Roma "La Sapienza", em 1994. Em dez anos, portanto, saiu da condição de aluno para tornar-se professor da Universidade Católica e da Universidade de São Paulo.

* Professor titular aposentado do Departamento de Direito Econômico, Financeiro e Tributário da Faculdade de Direito da Universidade de São Paulo. 
Isso sem falar que se casou com a Raquel, que lhe deu dois filhos, o Augusto e o Vittorio. O primeiro empresta o nome do grande criador do Império Romano e outro que o tem ligado ao primeiro rei depois da Unificação italiana, Vittorio Emanuelle.

A estrutura familiar sólida lhe permite tempo para o prosseguimento dos estudos que não cessam. Não vou me ater a seu currículo de publicações, de ensaios, de artigos, de participação em entidades nacionais e internacionais, de conferências que realiza por todo o mundo. A todas as Universidades empresta o brilho de sua inteligência. A seus alunos é guia que dá norte seguro. A seus colegas têm sempre um abraço amigo de acolhimento.

Ao lado de tanta atividade intelectual, participa, ainda, da solidificação do Estado brasileiro com preparação de projetos, bastando lembrar o de repatriamento de capitais, ora em discussão no Congresso Nacional.

Eis o homem que enxerga através do escuro.

A solenidade de hoje marca sua incorporação ao rol dos professores titulares da Faculdade de Direito da Universidade de São Paulo. É galardão buscado por muitos e obtido por poucos. O concurso é prova seletiva. Não há demérito para nenhum dos candidatos, pois um apenas é o indicado.

Todos os grandes homens do mundo cederam à fascinação que exerce aquilo que se ignora. Paul Klee, grande pintor e poeta suíço, disse que "a arte não reproduz o visível; faz visível". Nem é imitação como queriam Platão e Aristóteles, que pretenderam o mimetismo da produção artística. O artista torna visível o que até então não era. Octávio Paz ("El arco y la lira”), prêmio Nobel de literatura de 1990 disse que a poesia revela um mundo e cria outro.

São homens que viram e veem no escuro.

Assim Heleno Torres trata o direito. O apanhar da norma em seu momento estático é apenas a representação de uma vontade momentânea do grupo dominante. Heleno supera este momento para buscar a essência do comportamento humano. Por isso é que foi membro da comissão redatora da Carta Latino Americana de Direitos Fundamentais dos Contribuintes em Santiago de Compostela, na Espanha, em 2012. Nem por outro motivo é que todos seus escritos estão recheados de preocupação com o outro.

Daí decorre seu notável trabalho apresentado para conquista da titularidade de Direito Financeiro sobre a Teoria da Constituição Financeira. O trabalho deu sentido orgânico às normas de Direito Financeiro esparsas na Constituição Federal. Compilou-as numa surpreendente coesão temática dando-lhes tratamento adequado.

Não apenas isso. Não ficou na análise de textos jurídicos. Como disse acima, preocupou-se com o outro. Não em preocupação psicanalítica de pessoas ou instituições, mas na vertente dos relacionamentos humanos através das políticas públicas. 
$\mathrm{O}$ atendimento das necessidades da população não escapa de seu pincel, digo, de sua caneta. Aqui, o pintor se mescla com o escritor, com o poeta e com o fiel analista jurídico.

Quando cuida das políticas públicas está refletindo o sentimento de Castro Alves, o grande poeta abolicionista que, desta Casa disse “A praça, a praça é do povo. Como o céu é do condor".

Eis o homem que enxerga no escuro.

Como disse Paul Valéry, "a verdadeira fecundidade de um poeta não consiste no número de seus versos, mas muito mais na extensão de seus efeitos" ("Variedades", ed. Iluminuras, 2011, p. 27). Heleno desce a fundo em cada análise que efetua. Seu trabalho sobre os royalties do petróleo é obra-prima de análise das receitas provindas da exploração do patrimônio público.

Outra virtude de nosso homenageado é ter a humildade de saber ouvir. Sem prejuízo de seu grande conhecimento jurídico, sabe compreender quando alguém pondera sobre alguma coisa. Reflete, então, nosso grande Guimarães Rosa que disse: "Mestre não é quem ensina, mas quem de repente aprende". Daí o ciclo importante de sua atualização permanente. Não só consagrado como grande tributarista imergiu no Direito Financeiro, trazendo poderosa influência de seus ensinamentos. Teorizou sobre o complexo das normas de Direito Financeiro na Constituição Federal.

Heleno consegue reunir sólida formação jurídica com a flexibilidade do conhecedor das artes. As Arcadas são assim, um misto de dogma e de irreverência. Aqui se sente bater no peito heroica pancada. Aqui é o centro de produção jurídica do país. Aqui prevalece o diálogo; jamais imposições. Aqui é lugar certo para uma personalidade e um intelecto privilegiado como de Heleno Torres.

O homem que descobre a zona escondida do escuro, enquanto todos só veem o claro.

Daí e por isso é que comemoramos, hoje, sua posse solene no cargo de Professor Titular de Direito Financeiro.

Assuma suas funções, meu caro amigo e professor. Dê margem a sua imaginação, questione, discuta, aponte os caminhos que devem ser seguidos pelo Direito Financeiro, dando norte seguro a este país descontrolado, incerto, desgovernado e sem rumo. Seja timoneiro seguro a indicar caminhos. Apresente-se com sua enorme verve proativa

O empossando de hoje é o homem que conhece os caminhos, mesmo no escuro.

São Paulo, 21 de setembro de 2015. 
